\title{
Diverse spatial, temporal, and sexual expression of recently duplicated androgen-binding protein genes in Mus musculus Christina M Laukaitis ${ }^{1,2}$, Stephen R Dlouhy ${ }^{3}$, Richard D Emes ${ }^{4,5}$, Chris P Ponting ${ }^{4}$ and Robert C Karn*1
}

Address: ${ }^{1}$ Department of Biological Sciences, Butler University, 4600 Sunset Ave., Indianapolis, Indiana 46208, USA, ${ }^{2}$ Internal Medicine Residency Program, St. Vincent Hospital, 2001 W. 86th St., Indianapolis, Indiana 46260, USA, 33epartment of Medical and Molecular Genetics, Indiana University School of Medicine, 875 W. Walnut St., Medical Research and Library Building, Indianapolis, Indiana 46202, USA, ${ }^{4} \mathrm{MRC}$ Functional Genetics Unit, Department of Human Anatomy and Genetics, University of Oxford, South Parks Road, Oxford OX1 3QX, UK and ${ }^{5}$ Department of Biology, University College London, Darwin Building, Gower St., London, WC1E 6BT, UK

Email: Christina M Laukaitis - cxlaukai@stvincent.org; Stephen R Dlouhy - sdlouhy@iupui.edu; Richard D Emes - r.emes@ucl.ac.uk; Chris P Ponting - Chris.Ponting@anat.ox.ac.uk; Robert C Karn* - rkarn@butler.edu

* Corresponding author

Published: 14 July 2005

BMC Evolutionary Biology 2005, 5:40 doi:I0.1/86/147|-2/48-5-40

Received: 05 April 2005

Accepted: 14 July 2005

This article is available from: http://www.biomedcentral.com/I47I-2/48/5/40

(C) 2005 Laukaitis et al; licensee BioMed Central Ltd.

This is an Open Access article distributed under the terms of the Creative Commons Attribution License (http://creativecommons.org/licenses/by/2.0), which permits unrestricted use, distribution, and reproduction in any medium, provided the original work is properly cited.

\begin{abstract}
Background: The genes for salivary androgen-binding protein (ABP) subunits have been evolving rapidly in ancestors of the house mouse Mus musculus, as evidenced both by recent and extensive gene duplication and by high ratios of nonsynonymous to synonymous nucleotide substitution rates. This makes ABP an appropriate model system with which to investigate how recent adaptive evolution of paralogous genes results in functional innovation (neofunctionalization).

Results: It was our goal to find evidence for the expression of as many of the Abp paralogues in the mouse genome as possible. We observed expression of six Abpa paralogues and five Abpbg paralogues in ten glands and other organs located predominantly in the head and neck (olfactory lobe of the brain, three salivary glands, lacrimal gland, Harderian gland, vomeronasal organ, and major olfactory epithelium). These Abp paralogues differed dramatically in their specific expression in these different glands and in their sexual dimorphism of expression. We also studied the appearance of expression in both late-stage embryos and postnatal animals prior to puberty and found significantly different timing of the onset of expression among the various paralogues.

Conclusion: The multiple changes in the spatial expression profile of these genes resulting in various combinations of expression in glands and other organs in the head and face of the mouse strongly suggest that neofunctionalization of these genes, driven by adaptive evolution, has occurred following duplication. The extensive diversification in expression of this family of proteins provides two lines of evidence for a pheromonal role for ABP: I) different patterns of AbpalAbpbg expression in different glands; and 2) sexual dimorphism in the expression of the paralogues in a subset of those glands. These expression patterns differ dramatically among various glands that are located almost exclusively in the head and neck, where the sensory organs are located. Since mice are nocturnal, it is expected that they will make extensive use of olfactory as opposed to visual cues. The glands expressing Abp paralogues produce secretions (lacrimal and salivary) or detect odors (MOE and VNO) and thus it appears highly likely that ABP proteins play a role in olfactory communication.
\end{abstract}




\section{Background}

Genome sequences of primates and rodents [1-3] now allow genome-wide investigations of evolutionary rates and selective processes. The aforementioned studies, and earlier ones, show that mammalian protein-coding genes vary dramatically in their rates of sequence divergence [1,3-6] and that amino acid sequence divergence is greatest for secreted proteins whose genes are expressed in few tissues and least for intracellular proteins found widely in all tissues [7]. These generalizations hold for the great majority ( $90 \%$; [1]) of genes that are present in single copies in both primate and rodent genomes. The remaining genes have experienced at least one duplication in either one or both of the primate and rodent lineages.

The process of gene duplication provides material for functional diversification. A newly-duplicated gene may subsequently acquire innovative function ("neofunctionalization") or may retain some of its progenitor gene's functional repertoire ("subfunctionalization"), or a combination of both [8-11]. Such duplicated genes are also rapidly diverging in sequence $[1,3]$ and they are substantially over-represented in functions relating to chemosensation, reproduction, host defense and immunity, and toxin metabolism. Innovation within these functional categories therefore can occur by sequence divergence and/or gene duplication. Adaptive evolution however can also act by modifying gene expression profiles, for example by restricting expression to few tissues. Among genes conserved as single orthologous copies among primate or mouse species, expression variation appears to evolve neutrally and approximately linearly with time $[12,13]$.

We were interested in a related question: How rapidly can expression profiles diverge among duplicated genes? For example, Gu [14] showed an increase in expression diversity in genes involved in Drosophila development. We wish to ask about diversification during other evolutionary process, to wit rapidly diverging duplicated genes involved in the four functions listed above. Because expression patterns appear to diverge substantially over long time periods, such as since the primate-rodent (Euarchontoglires) common ancestor $[15,16]$, it is necessary to address this question using many related genes that arose only in very recent times. The most closely-related vertebrate genomes available currently are those of mouse and rat; these lineages diverged approximately 12-24 million years ago (Mya) $[17,18]$. Thus, by comparing these two genomes we may be able to identify a gene family that is extensively expanded in one, but not necessarily in the other genome, with which to investigate recent expression divergence.

Indeed, we recently identified two families of paralogous genes, clustered together in a 1-2 Mb region of Mus mus- culus chromosome 7 that each meet this criterion. We predict that the Euarchontoglires common ancestor, and the rat and mouse common ancestor, each contained a single member of both gene families; these family members were proximally positioned in a tightly linked head-tohead (bidirectional) gene pair $[19,20]$. In humans and chimpanzees these genes have accumulated disruptive mutations and are thus likely to be nonfunctional pseudogenes. In the rat lineage, two gene pair duplications have given rise to three gene versions in each family. In the mouse lineage, an extraordinary and rapid burst of duplications has generated over a dozen members of each family, some of which harbor inactivating mutations, whereas others are full-length and apparently functional. Because these mouse genes appear to have all arisen via duplication events since the mouse-rat divergence (12-24 Mya), these are the genes we have chosen to investigate to address the issue of expression divergence.

The two families are termed Abpa and $A b p b / A b p g$ genes (encoding $\mathrm{ABP} \alpha$ and $\mathrm{ABP} \beta / \mathrm{ABP} \gamma$ proteins). They are named according to their proteins that were first described in the literature $[21,22]$. Androgen-binding protein $\alpha$ subunit $(\mathrm{ABP} \alpha)$ forms covalently linked heterodimers with either $\beta$ or $\gamma$ subunits, and these are secreted into the saliva following expression in the submaxillary gland. $\mathrm{ABP} \alpha$, $\mathrm{ABP} \beta$ and $\mathrm{ABP} \gamma$ proteins are secretoglobins, a family of secreted proteins [23] that bind lipophilic ligands (for a review, see [24]) and are present in mammals and birds $[25,26]$, but whose roles in cellular and physiological function all remain obscure $[27,28]$.

Much of the previous work on salivary ABP has focused on determining its function [22]; reviewed briefly in [25]. Laboratory tests of female preference for males carrying different genetic variants of salivary ABP have provided evidence that the protein may mediate sexual preference $[29,30]$. A role in sexual selection is consistent with the evidence for positive selection in the microevolution of the gene (Abpa) for the $\alpha$ subunit, which has a different allele fixed in each of three subspecies of Mus musculus $[31,32]$. These Abpa alleles show significantly reduced polymorphism both in their exons and introns and high ratios of nonsynonymous to synonymous nucleotide substitutions $\left(\mathrm{K}_{\mathrm{A}} / \mathrm{K}_{\mathrm{S}}\right)$ in the coding region $[33,34]$. Fixation of different alleles of Abpa in the subspecies of Mus musculus has been proposed to have occurred by selective sweeps [33]. Abpb and $A b p g$ also have high $\mathrm{K}_{\mathrm{A}} / \mathrm{K}_{\mathrm{S}}$ values, suggesting that their microevolution has also been driven by positive selection $[19,20,22]$.

Here we investigate the expression of 17 predicted $A b p a$, $A b p b$ and $A b p g$ genes in 23 mouse glands and other organs. We chose organs and glands to obtain as wide a representation of gene expression in the mouse as 
possible. We specifically included any tissues where expression of other secretoglobins has been identified (Harderian gland, lacrimal gland, lung, kidney, uterus, skin/sebaceous glands, salivary glands and prostate; [25]). In the head we surveyed the brain and (separately) olfactory lobes, parotid glands, sublingual glands, submaxillary glands, lacrimal glands, major olfactory epithelium (MOE), vomeronasal organ (VNO) and Harderian glands; in the body, we tested skin, adrenal gland, heart, spleen, kidney, testis, lung, liver, pancreas, small intestine, bladder, prostate, ovary and uterus. To test for expression similarity or divergence among paralogous genes we sought to identify transcripts in spatially-distinct tissues and from embryonic or adult individuals of different ages and/or sexes. Our results show how adaptive evolution among paralogous genes has led to expression divergence within a relatively short (12-24 My) period of time. We use these expression patterns to develop a model of paralogue neofunctionalization.

\section{Results}

Our goal was to survey the glands and other organs of male and female, embryonic, juvenile and adult mice for expression of nine Abpa and eight Abpbg paralogues previously predicted from the mouse genome to be full-length and apparently functional. Hereinafter $A b p a$ and $A b p b g$ paralogous genes will simply be identified as " $a$ " and " $b g$ " with numerical suffixes as described previously [19]. We developed primer sets specific for each putative Abp gene (Fig. 1), excluding those paralogues that are predicted to be pseudogenes [19]. Forward and reverse primers of each set fall in exons 2 and 3, respectively (see [20], for the structures of the $\mathrm{ABP} \alpha, \beta$ and $\gamma$ subunit genes) in order that a much larger product (ca. 1-1.2 kb) is obtained when genomic DNA is the template, compared to that obtained from cDNA templates (ca. 200-300 bp). This design allowed us to test the primer sets, using genomic DNA as templates. Each primer pair amplified a product of the expected size from genomic DNA (not shown). In preliminary experiments the RNA extracted from $\mathrm{C} 3 \mathrm{H} /$ HeJ tissues and subsequently used to make cDNA was contaminated with genomic DNA (Fig. 2, Panel A). In subsequent experiments we removed the contaminating genomic DNA by RNase-free DNase treatment, as shown in Fig. 2 (Panel B). In all cases where transcripts were detected, they were of the expected sizes. We verified a representative of each paralogue with DNA sequencing.

The quality of the cDNA made from RNA extracts was tested using an internal control, a primer set designed to amplify the housekeeping gene Gapdh [35]. Only cDNA that showed the clear presence of a band of the expected size with the Gapdh primers was subsequently tested for Abpa/Abpbg transcripts (see Fig. 2, Panel B for an example of Gapdh expression). Because RNA preparations were treated with RNase-free DNase prior to their use as templates in PCR reactions, the product obtained with the Gapdh primers could confidently be ascribed to amplification of that transcript, rather than to the amplification of pseudogenes of corresponding size [36].

Although it was not our purpose in this study to precisely quantitate levels of expression of the individual paralogues, we did note reproducible variation in intensity of RT-PCR products. A series of dilutions of a typical template indicated that we could detect expression over a broad range. Most expressing tissues gave a negative result between $10^{4}$ and $10^{6}$ dilution.

\section{Detection of transcripts in adult tissues}

cDNA from 23 glands and other organs of adult $\mathrm{C} 3 \mathrm{H} / \mathrm{HeJ}$ mice was tested for the presence of transcripts of nine $A b p a$ paralogues and eight Abpbg paralogues. As detailed below, we have found evidence of $A b p$ expression in 10 of these glands/organs, and we demonstrate that multiple members of these gene families are differentially expressed. Equivalent amounts of RNA were tested for each tissue. All experiments in both male and female mice were repeated using tissue independently isolated from a second animal.

Figure 2 compares the expression of these paralogues in the major olfactory epithelium (MOE) of adult male (Fig. 2A) and female (Fig. 2B) mice. In both sexes, a11, bg11, $a 10$, and $b g 8$ were expressed. As the female also expressed $a 2$ and $b g 2$, whereas no expression was observed in the male, this represents a likely example of sexual dimorphism of expression. Gene expression in the submaxillary gland is shown in Fig. 3A and 3B. Expression of the a11, bg11, and bg10 paralogues was found in both male and female submaxillary glands. This was expected from previous findings on the $A B P \alpha, \beta$ and $\gamma$ subunit genes, respectively, in the submaxillary gland and its secretions $[21,22,37,38]$. In addition, the female submaxillary gland exhibits expression of $a 10, a 13$ (weak) and $b g 8$, suggesting that sexual dimorphism in $A b p$ expression also occurs for this gland.

Differential $A b p$ expression and sexual dimorphism of $A b p$ expression was strikingly apparent in the lacrimal gland where distinct arrays of $A b p$ paralogue expressions are seen (Fig. 3C and 3D). By contrast to the MOE and the submaxillary glands, the lacrimal does not show expression of $a 11$ or $b g 11$ in both sexes. Rather, $a 2, a 8, a 13, b g 2$ and $b g 8$ are expressed in both sexes, while the male, but not the female, also expresses $a 5, a 10$, and $b g 12$. It is also striking that the female olfactory and accessory olfactory lobes $(\mathrm{O} / \mathrm{AO}$ combined) did not express $A b p$ paralogues, while the male $\mathrm{O} / \mathrm{AO}$ lobes expressed $a 2, a 13, b g 2$ and bg8, as summarized in Fig. 4. 


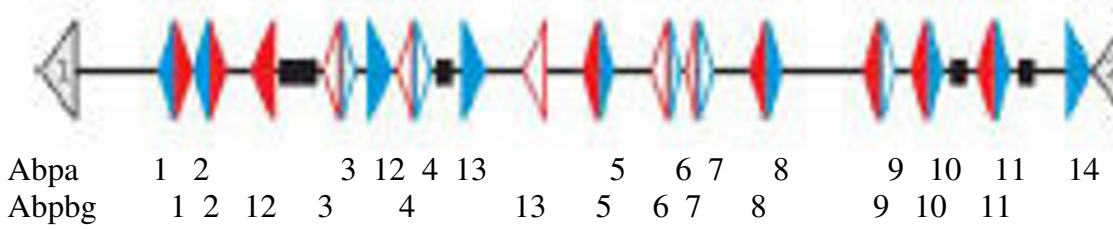
Mouse Chr 7

Control primers $\left(5^{\prime}-3^{\prime}\right)$

$\begin{array}{lll}\begin{array}{l}\text { Glyceraldehyde } \\ \text { phosphate } \\ \text { dehydrogenase }\end{array} & \text { GAPDH F } & \text { CAACGACCCCTTCATTGACC } \\ \text { GAPDH R1 } & \text { CTCCACGACATACTCAGCAC }\end{array}$

Abpa primers $\left(5^{\prime}-3^{\prime}\right)$ Mouse salivary androgen-binding protein alpha-like paralogues Abpa1 F CATGATGTCCAACTATTTCTTTATG Abpa1 R GCAAGTAACCAGGCAAGTGGC Abpa2 F Abpa2 R Abpa5 F Abpa5 R Abpa8 F Abpa8 R Abpa10 F Abpa10 R Abpa11 F Abpa11 R Abpa12 F Abpa12 R Abpa13 F Abpa13 R Abpa14 F CAGAAGAGTATGTTAATTATGTGGAG AAAGATGTAGCCATCAACATAACGG AGGATGTTCACCTATTTTTAAACAG GCTGGCTGGCTTCTATTTTTC GATGTTCATCTATTCTTTCACAGG AAGATGCAAACATCAACATGCTGGT AAGAGTATGTTGAGTACCTGAAACC CTGGTGAGCAGGCAAATGG Abpa14 R ACAGAGAAAAGTTGATTTATTTTTGAATG GGAGGCAATTGGTTTCCG GAGGAGGTTCGTCTATTTTTAAACG AAGTTAGAGCCATCAACATAGTGT GAGGATGTTCGTCTATTTTTAAATG TAGGCAGGCAAGTGGCTTCC AACAATACAATAATGACCCTCTCG ACTGGTGAGCAGCTAAGTGGC

Expected product size 190 bp Expected product size $238 \mathrm{bp}$ $174 \mathrm{bp}$ $185 \mathrm{bp}$ $201 \mathrm{bp}$ 203 bp 234 bp $205 \mathrm{bp}$ $232 \mathrm{bp}$ $183 \mathrm{bp}$

Expected product size

Abpbg primers (5' - 3') Mouse salivary androgen-binding protein beta/gamma-like paralogues Abpbg1 F Abpbg1 R Abpbg2 F GGGTGTCGTCTCTGGATACA CAAGACTTCTTTGGTATAATATGACT TTTGGGTATTCTCTCTGGAAACA Abpbg2 R AGAATGTTCTTCAAGACTTCTTTG 205 bp Abpbg5 F TGCAAGTGTTGTCTCTGGAAGT Abpbg5 R Abpbg8 F GTCCTAATAGCTTCGAAAGAAGG GCTGGTGTTATCTCAGGAAGCA Abpbg8 R CGTAAAGGTTTCTTCGGAATAGT Abpbg9 F GCAGTACTCTCTGGACTTAAGAT Abpbg9 R Abpbg10 F Abpbg10 R Abpbg11 F Abpbg11 R Abpbg12 F Abpbg12 R CCATGTCTTGATAAATAGAAGCC CGGAGCAATACTTACTCTAAGG CTTTAAGAGGTCATTGCCATAGT TAAAATACTGGGTGGAAATAGGC CCGCCATTTTGTTTACAGAATCT TTGAGCACTGTCTCTGGGAAAA CATCCATTTCTTGGTAATCACAC

$216 \mathrm{bp}$

242 bp

207 bp

233 bp

208 bp

215 bp

$240 \mathrm{bp}$

\section{Figure I}

Primer sets used in this study. The order of the AbpalAbpbg paralogues in the mouse genome is shown at the top and the expected size of the PCR product obtained with each primer set is shown to the right of the reverse primer in that set. The 5to-3 orientations of the genes are shown by the direction of the arrowheads. Abpa-like genes are shown in blue and Abpbg-like genes in red. Filled arrowheads represent predicted functional genes whereas open arrowheads denote predicted pseudogenes. Gaps $(>5 \mathrm{~kb}$ ) in the genomic assembly of each species are shown as black boxes. 


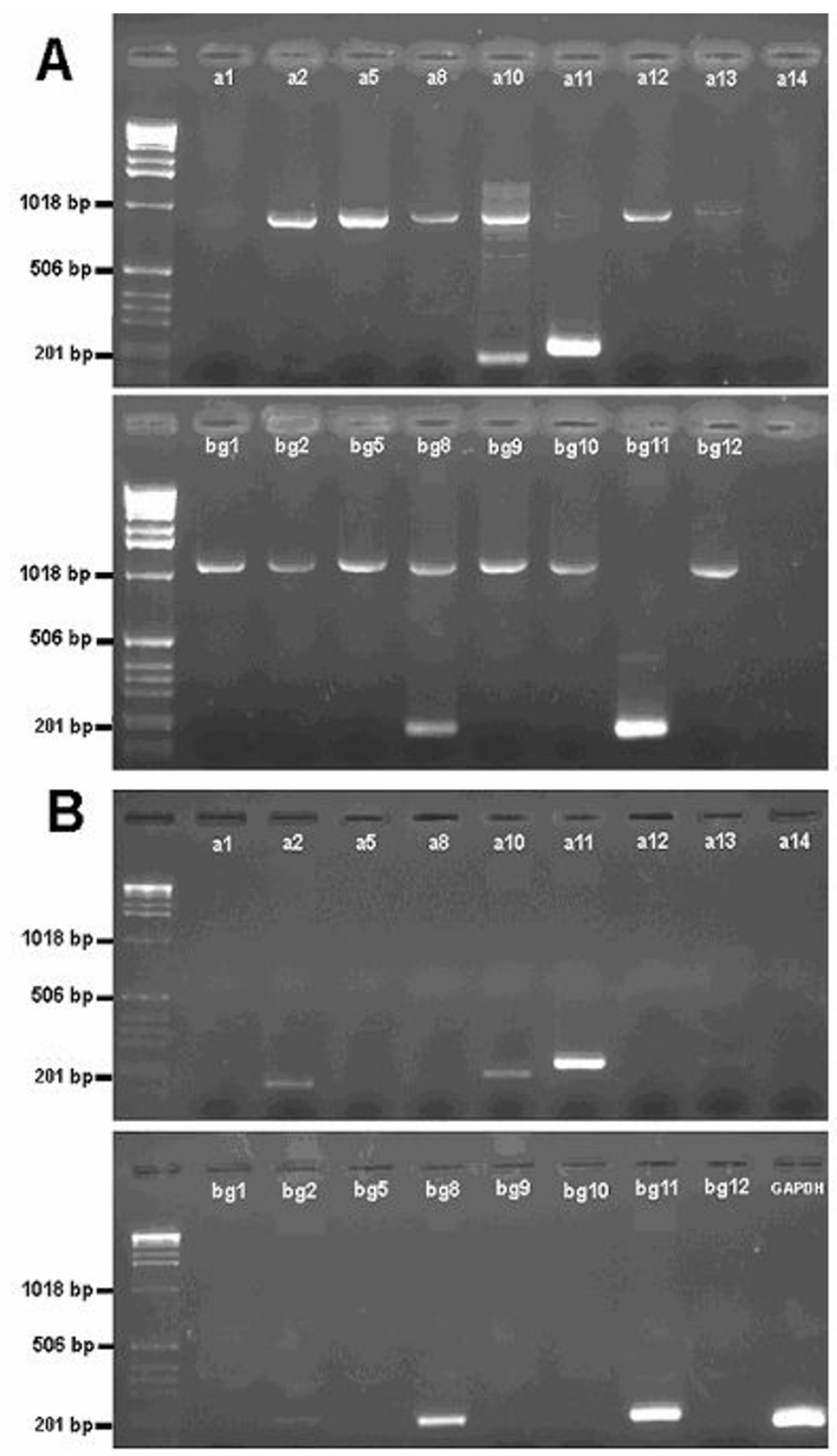

Figure 2

Detection of transcripts in the major olfactory epithelium (MOE) of the mouse. RNA purified from the $\mathrm{MOE}$ of $\mathrm{C} 3 \mathrm{H} / \mathrm{HeJ}$ mice was used to make cDNA, which was used as template in PCR reactions that included, separately, the nine Abpa primer sets, the eight Abpbg primer sets and the Gapdh control primer set. The left-hand lane in all gels contained DNA size markers. Panel A: MOE from a male, where the RNA preparation was used to make cDNA without first being treated with RNase-free DNase. The larger band $(>I \mathrm{~kb})$ that appears in most lanes is the amplification product from genomic DNA that contaminated the RNA preparation. Panel B: MOE from a female, where the RNA preparation was treated with RNase-free DNase before it was used to make cDNA. No genomic amplification products appear on this gel. 

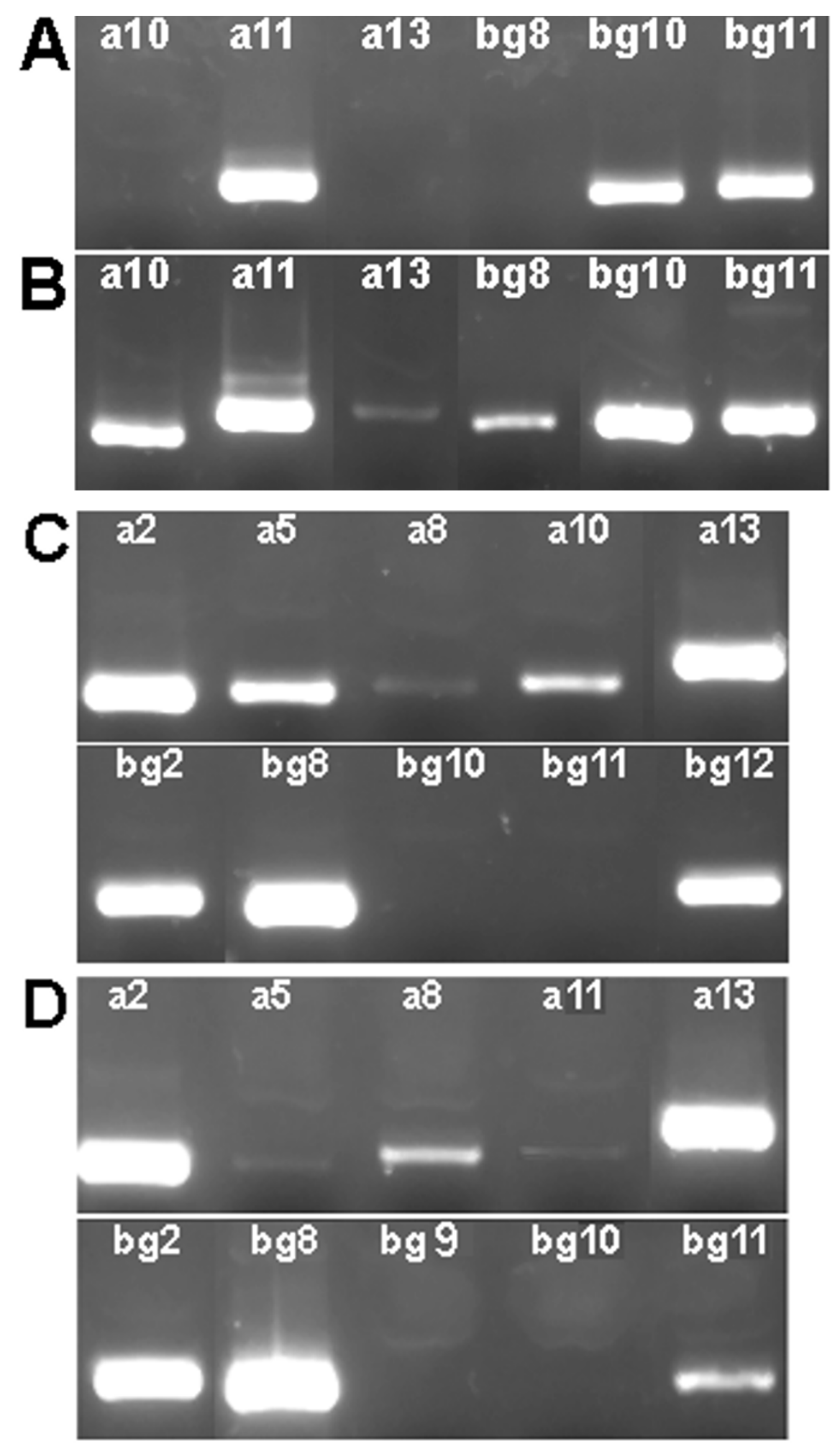

\section{Figure 3}

Detection of transcripts in the submaxillary and lacrimal glands of the mouse. Expression testing was done as described in the text and in the legend of Fig. 2. Panel A: Submaxillary gland expression in males; Panel B: Submaxillary gland expression in females; Panel C: Lacrimal gland expression in males; Panel D: Lacrimal gland expression in females. 


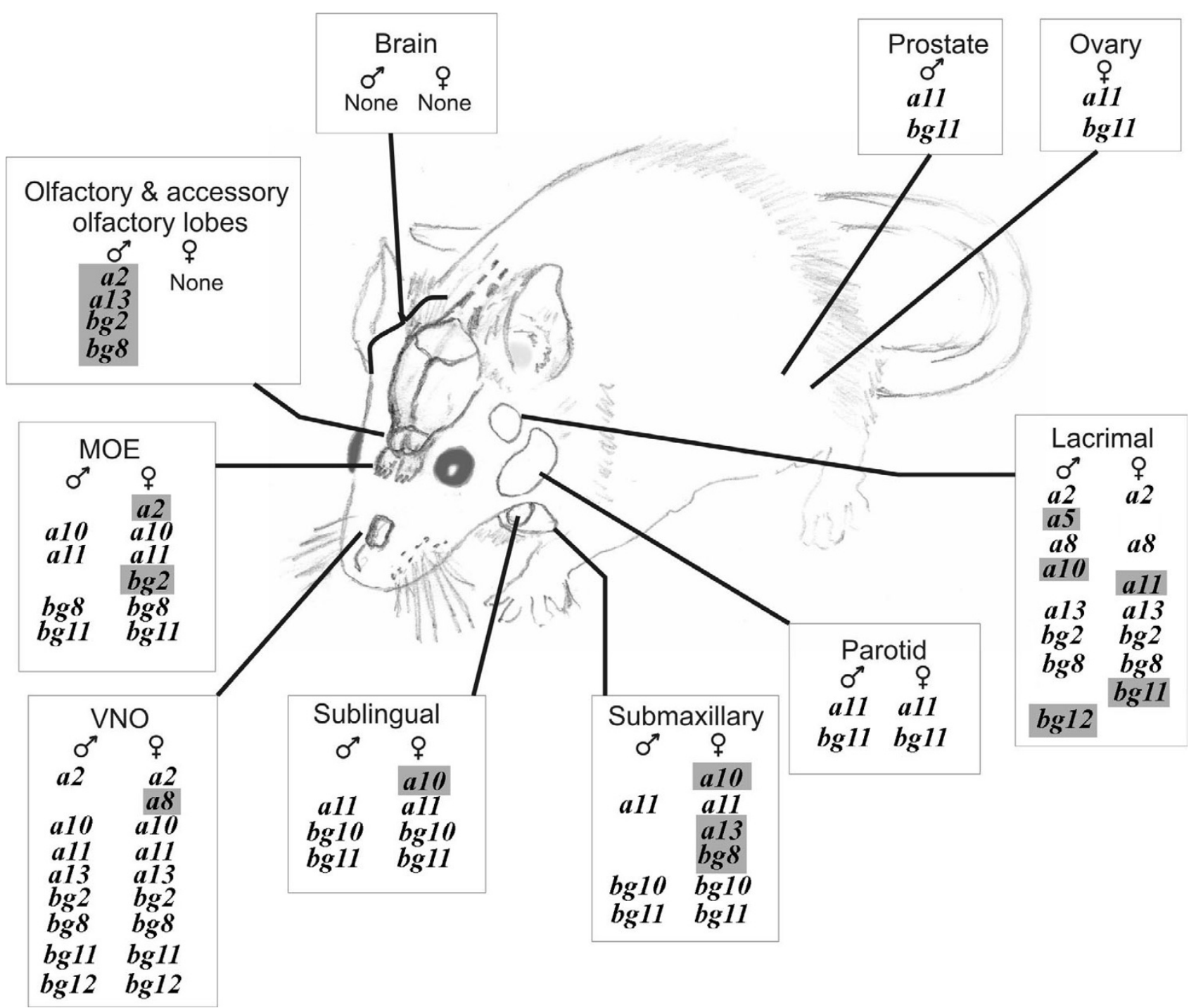

Figure 4

Abp paralogue expression shown on a diagram of the glands/organs of a mouse, with expression in males and females differentiated. Paralogues which exhibited sexually dimorphic expression are shaded in grey.

The expression patterns for all the glands and other organs that tested positive for $A b p$ expression are summarized in Fig. 4 (the Harderian gland showed only faint bands for a few paralogues in one sex and thus is not included in the figure). We previously suggested that pairs of adjacent $a$ and $b g$ genes (i.e. those that are identically numbered) might be co-expressed in single tissues or organs [19]. Certainly, the expression of $a 2$ and $b g 2$ paralogues appears correlated. The most commonly expressed paralogues are $a 11$ and $b g 11$ and, although their expression is not ubiquitous, in all cases they are co-expressed. In female sub- maxillary and sublingual glands, $a 10$ and $b g 10$ are both expressed, along with $a 11$ and $b g 11$, while only $b g 10$ is expressed with $a 11$ and $b g 11$ in males. The $b g 10$ paralogue is co-expressed with $a 11$ and $b g 11$ only in submaxillary and sublingual glands, but not in parotid glands. The parotid gland data are consistent with other findings [38]. bg10 is co-expressed with its genomic partner $a 10$ only in the female submaxillary gland. The $a 10$ paralogue is expressed in a sexually dimorphic manner in the lacrimal, submaxillary and sublingual glands and in both sexes in the vomeronasal organ (VNO) and the MOE (Fig. 4). 
Other paralogues $(a 5, a 8, a 13, b g 8$, and $b g 12)$ are expressed sporadically in various glands. Of these, only $a 5$ and $b g 8$ are members of $a-b g$ pairs in the genome assembly (Fig. 4), but expression of a5 only occurs once (male lacrimal), while expression of its partner (bg5) was never observed; $b g 8$ expression often occurs without that of its partner, $a 8$. Notable for the absence of expression in any glands or other organs tested were $a 1, a 12, a 14, b g 1, b g 5$ and $b g 9$; of these, $a 12, a 14$ and $b g 9$ are not paired with full-length $a / b g$ genes, and thus might be pseudogenes despite their full-length coding sequences. On the other hand, $a 1$ and $b g 1$ and $a 5$ and $b g 5$ are paired in the genome so there appears to be no absolute rule determining whether paired or unpaired paralogues are expressed.

Thirteen glands and other organs tested negative for $A b p$ expression, including brain, skin, adrenal gland, heart, spleen, kidney, testis, lung, liver, pancreas, small intestine, bladder and uterus. With the exception of skin and brain, these are mostly of endodermal and mesodermal origin and are located in the body cavity. By contrast, the glands that show $A b p$ paralogue expression are mostly ectodermal in their origins, with the exception of the submaxillary and sublingual glands, which are endodermal.

Figure 5 provides another perspective where the $A b p$ expressions for the two sexes are arrayed on phylogenetic trees of the Abpa and $A b p b g$ paralogues with the intent of discovering possible correlations of expressions of these genes with their evolutionary history. Whilst, this treatment does not reveal any such correlations, it does highlight the sex-limited feature of the expression of many of these $A b p$ paralogues.

\section{Detection of transcripts in embryos and early postnatal stages}

We were interested in determining when the transcripts seen in adult tissues first appear in development. For reference, embryo day 21 (e21) is the day before birth in an average gestation period; the eyes open at day six-seven on average, and the animal goes through puberty at day 3032 on average in this strain. Therefore we examined embryos at days 13, 17 and 21 of gestation and animals at postnatal days one, six and 15 for expression. RNA was extracted from the entire heads of embryos at 13, 17 and 21 days of gestation, as well as a postnatal day one animal. In the case of days six and 15, we could dissect the combined submaxillary/submandibular region, the brain, the lacrimal glands and the combined MOE/VNO region and for each we were able to generate cDNA. The results for the submaxillary gland and lacrimal gland in the day 15 male are shown in Fig. 6; identical results were observed for the same tissues from day 15 females. The submaxillary gland showed expression of two pairs of paralogues: a10/bg10 and $a 11 / \operatorname{bg} 11$, as well as the individual paralogues $\operatorname{bg} 8$ and a13. The lacrimal gland showed expression of four pairs of genes: $a 2 / b g 2, a 8 / b g 8, a 10 / b g 10$ and $a 11 / b g 11$, and three unpaired paralogues: $a 5, a 13$ and $b g 12$.

The results over the whole developmental time period are shown in Fig. 7, where they are also compared to the expression data observed in the adult tissues. We find that:

1) The $a 11 / b g 11$ pair and $b g 10$ are expressed in the head between $\mathrm{e} 13$ and birth;

2) Immediately following birth (i.e., day one), expression of $b g 10$, and $a 11 / b g 11$ appears but there is no evidence of any of the other paralogues that eventually are expressed in various tissues in the head (Fig. 5);

3) By day six, however, expression of other paralogues (i.e., in addition to $b g 10$, and $a 11 / b g 11$ ) appears in the submaxillary glands $(a 2 / b g 2, b g 8, a 10$, and $a 13)$ and the lacrimal glands $(a 2 / b g 2, a 5, a 8 / b g 8, a 10, a 13$ and $b g 12)$;

4) By contrast, the MOE/VNO region only expresses a11 and $b g 11$ at day six, and $b g 10$ and $a 11 / b g 11$ at day 15 . By this time point, there is no evidence as yet of paralogues (i.e., $a 2 / b g 2$, a13, a8/bg8 and $b g 12$ ) that are expressed in these tissues in adults;

5) It is also evident that the sexual dimorphism in expression of some of these paralogues has yet to occur by day 15 .

\section{Discussion}

The recent sequencing of numerous genomes has made possible comparative studies aimed at enhancing our understanding of gene evolution. It is clear from studies of mammalian genomes that the vast majority of genes have strongly conserved their coding sequences, and generally occur only in single copies [1-3]. Genes involved in adaptation and functional innovation, on the other hand, often show the footprints of positive selection in elevated ratios of nonsynonymous to synonymous nucleotide substitutions rates $\left(\mathrm{K}_{\mathrm{A}} / \mathrm{K}_{\mathrm{S}} ;[39]\right)$ in their coding regions. In addition, they are subject to frequent duplication, deletion and pseudogene formation [40]. Prevalent amongst rapidly evolving genes are those involved in immunity, reproduction, chemosensation and toxin metabolism [40].

Mouse salivary androgen-binding protein genes Abpa and Abpbg have evolved under strong positive selection $[19,31,33,34,41]$ and they have been duplicated extensively, mostly in pairs of $A b p a / A b p b g$ genes, across a 1-2 $\mathrm{Mb}$ region of mouse chromosome 7 [19]. This has been a recent expansion peculiar to the mouse, since the rat genome contains only three pairs of $A b p a / A b p b g$ para- 
Figure 5

\begin{tabular}{|c|c|}
\hline O/AO & \\
\hline MOE & \\
\hline VNO & \\
\hline Sbln & \\
\hline Sbm & \\
\hline Lac & \\
\hline
\end{tabular}
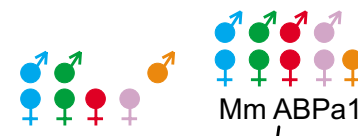
$\mathrm{Mm}$ ABPa11 Mm ABPa10

$\mathrm{Rn} \mathrm{ABPa} 2$

$\int_{97.7} \mathrm{Rn} \mathrm{ABPa3} / \mathrm{Rn} A B P a 1$

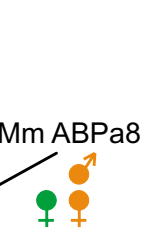

$\mathrm{Mm}$ ABPa9

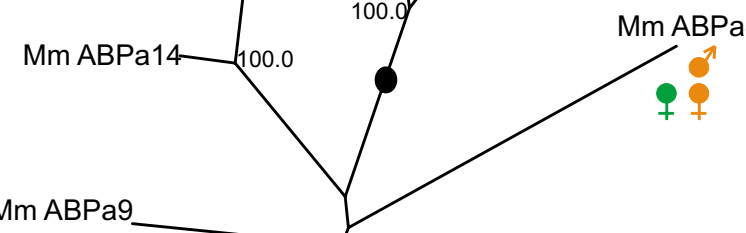

$\mathrm{Mm}$ ABPa7
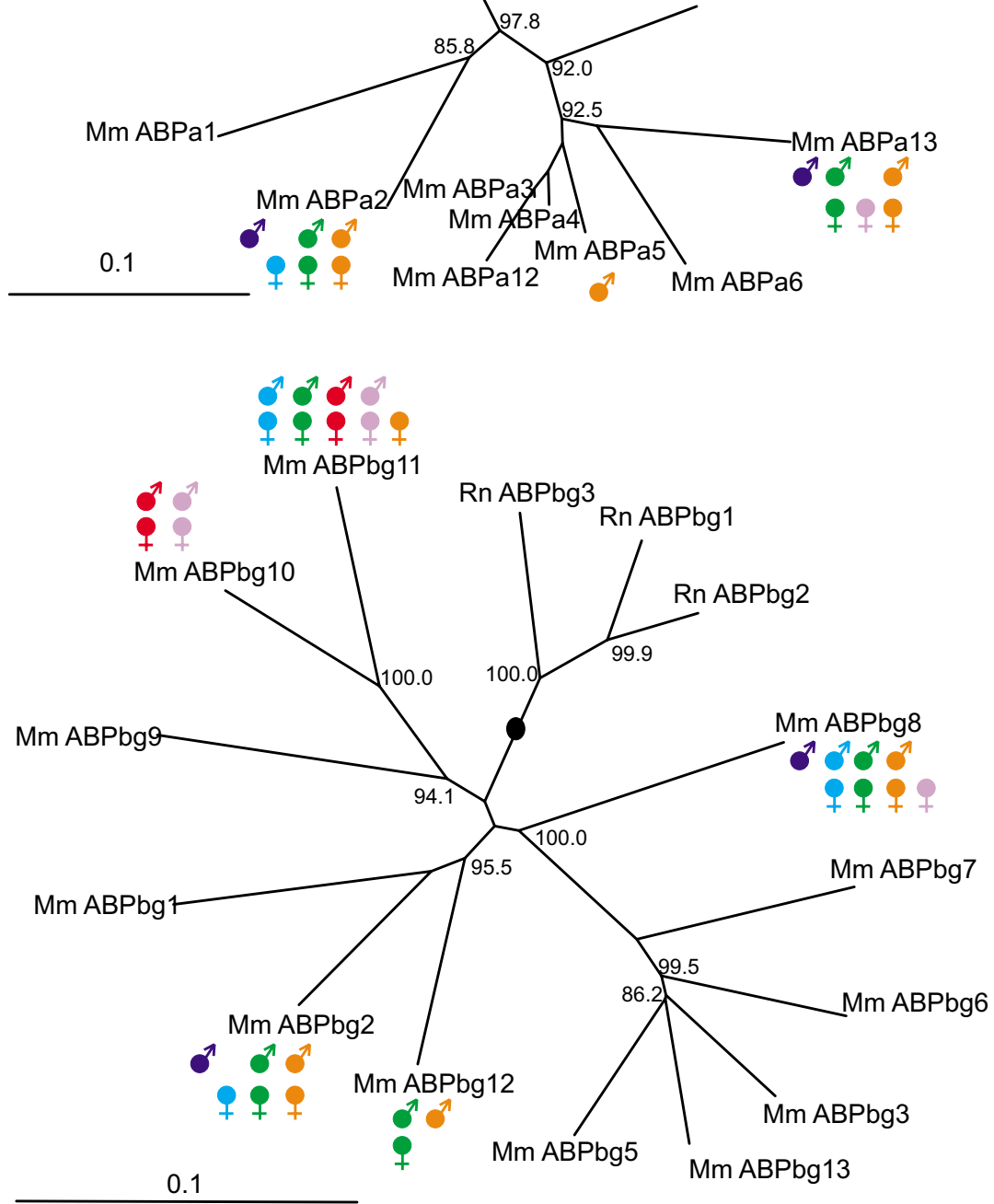

Figure 5

Expressions of $A b p$ paralogues painted onto 5' trees which represent phylogenetic relationships among the 5' regions of rodent Abpa-like and Abpbg-like genes 19. For simplicity, the expression in parotid and prostate/ovary, which is identical in the two sexes ( $a$ l l and bg / I only), has been omitted. The trees were generated with repeat-masked genomic DNA sequences 300 bp and I kb, respectively, 5 ' to the translational start sites of Abpa and Abpbg genes (see 19 for details). The lineages containing the proposed roots of the trees are shown by black dots and bootstrap values $>80 \%$ are shown. The key to the expressions in various tissues in the two sexes is shown at the upper right (abbreviations: $\mathrm{O} / \mathrm{AO}=$ olfactory/accessory olfactory bulbs; $\mathrm{MOE}=$ major olfactory epithelium; VNO = vomeronasal organ; Sbln = sublingual gland; Sbm = submaxillary gland; Lac = lacrimal gland). 

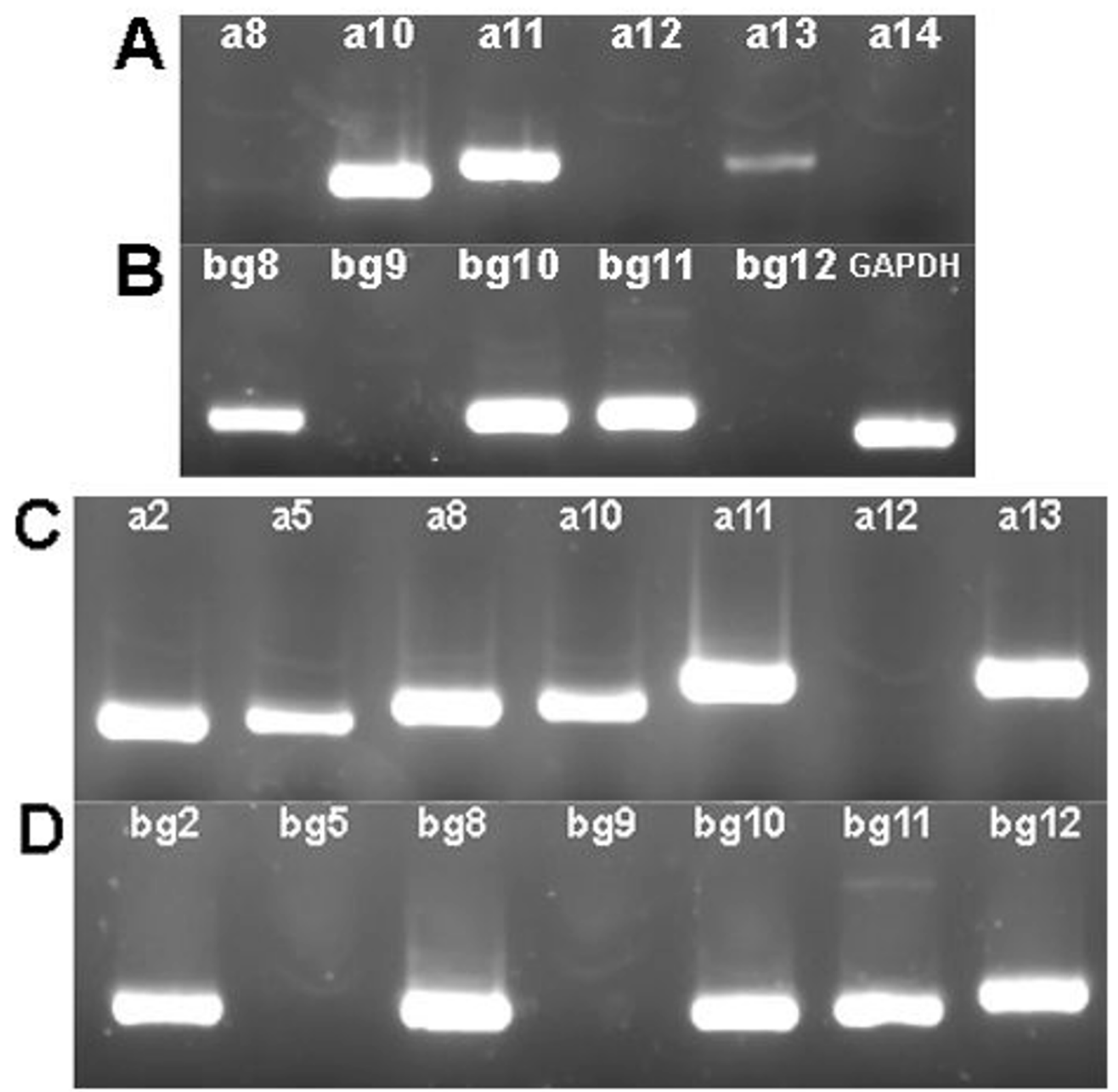

\section{Figure 6}

Detection of transcripts in the submaxillary and lacrimal glands of the postnatal day I 5 mouse. Expression testing was performed as described in the text and in the legend of Fig. 2. Panels A and B: Submaxillary gland expression of Abpa and Abpbg, respectively, in males; Panels $C$ and D: Lacrimal gland expression of $A b p a$ and $A b p b g$, respectively, in males. Expression in female submaxillary and lacrimal glands was identical to the male glands at this stage of development.

logues, and the human and chimpanzee genomes contain only a single pair whose members are both pseudogenes. These and other observations led to the hypothesis [19] that the common ancestor of mice and rats possessed only a single $A b p a / A b p b g$ gene pair.
The recently released dog genome contains a single fulllength $A b p a / A b p b g$ pair, a finding which supports our proposal that this is the ancestral state in eutherian mammals [19]. The cat genome also contains at least one Abpa/Abpbg pair and these are expressed as the subunits of the Fel dI 


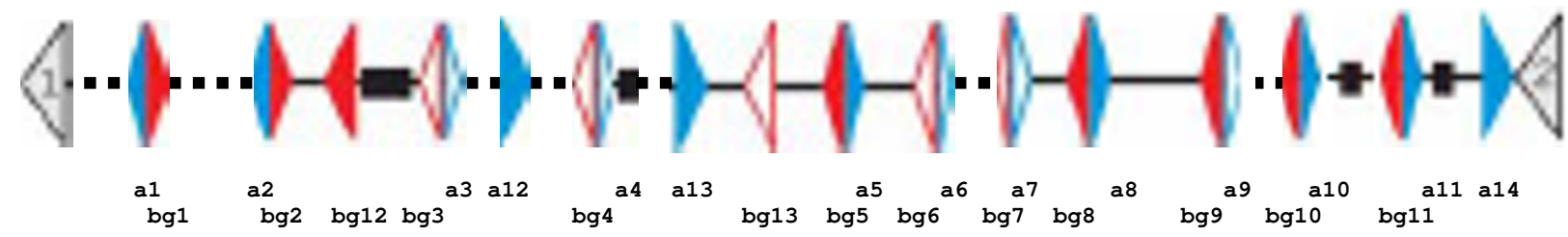

\begin{tabular}{|c|c|c|c|c|c|c|c|c|c|c|c|c|c|c|c|c|c|c|c|c|c|c|c|c|c|c|c|c|}
\hline \multicolumn{29}{|l|}{ Head } \\
\hline$\overline{e-d a y}$ & 13 & - & - & - & - & - & . & . & - & . & . & - & . & - & - & . & . & . & . & - & - & - & . & + & - & + & + & - \\
\hline e-day & 17 & - & - & - & - & - & . & . & - & . & . & - & . & - & - & . & . & . & . & - & - & - & . & - & - & + & + & - \\
\hline e-day & 21 & - & - & - & - & - & . & . & - & . & . & - & . & - & - & . & . & . & . & - & - & - & . & - & - & + & + & - \\
\hline pn-day & 1 & - & - & - & - & - & . & . & - & . & . & - & . & - & - & . & . & . & . & - & - & - & . & + & - & + & + & - \\
\hline \multicolumn{29}{|c|}{ Submaxillary } \\
\hline pn-day & $6^{1}$ & - & - & + & + & - & . & . & - & . & . & + & . & - & - & . & . & . & . & + & - & - & . & + & + & + & + & - \\
\hline \multirow{2}{*}{ pn-day } & $150^{*}$ & $0^{x}-$ & - & - & - & - & . & . & - & . & . & + & . & - & - & . & . & . & . & + & - & - & . & + & + & + & + & - \\
\hline & & - & - & - & - & - & . & . & - & . & . & + & . & - & - & . & . & . & . & + & - & - & . & + & + & + & + & - \\
\hline \multirow{3}{*}{$\begin{array}{l}\text { Adult } \\
\text { Lacrim }\end{array}$} & $x$ & - & - & - & - & - & . & . & - & . & . & - & . & - & - & . & . & . & . & - & - & - & . & + & - & + & + & - \\
\hline & & - & - & - & - & - & . & . & - & . & . & + & . & - & - & . & . & . & . & + & - & - & . & + & + & + & + & - \\
\hline & \multicolumn{28}{|c|}{ Lacrimal } \\
\hline pn-day & $\overline{6}$ & - & - & + & + & + & . & . & - & . & . & + & . & & + & . & . & . & . & + & + & - & . & + & + & + & + & - \\
\hline \multirow{2}{*}{ pn-day } & $150^{x}$ & $0^{x}-$ & - & + & + & + & . & . & - & . & . & + & . & - & + & . & . & . & . & + & + & - & . & + & + & + & + & - \\
\hline & 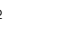 & - & - & + & + & + & . & . & - & . & . & + & . & - & + & . & . & . & . & + & + & - & . & + & + & + & + & - \\
\hline \multirow{2}{*}{ Adult } & 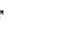 & - & - & + & + & + & . & . & - & . & . & + & . & & + & . & . & . & . & + & + & - & . & - & + & - & - & - \\
\hline & & & - & + & + & - & . & . & - & . & . & + & . & & - & . & . & . & . & + & + & - & . & - & - & + & + & - \\
\hline \multicolumn{29}{|c|}{ MOE/VNO } \\
\hline pn-day & 6 & - & - & - & - & - & . & . & - & . & . & - & . & - & - & . & . & . & . & - & - & - & . & - & - & + & + & - \\
\hline pn-day & $150^{\pi}$ & $0^{x}-$ & - & - & - & - & . & . & - & . & . & - & . & - & - & . & . & . & . & - & - & - & . & - & + & + & + & - \\
\hline 우 & & - & - & - & - & - & . & . & - & . & . & - & . & - & - & . & . & . & . & - & - & - & . & - & + & + & + & - \\
\hline Adult $\sigma^{*}$ & VNO & $0-$ & - & + & + & + & . & . & - & . & . & + & . & - & - & . & . & . & . & + & - & - & . & - & + & + & + & - \\
\hline Adult + & VNO & $0-$ & - & + & + & + & . & . & - & . & . & + & . & - & - & . & . & . & . & + & + & - & . & - & + & + & + & - \\
\hline Adult $\sigma^{*}$ & MOE & $\mathbf{E}-$ & - & - & - & - & . & . & - & . & . & - & . & - & - & . & . & . & . & + & - & - & . & - & + & + & + & - \\
\hline Adult + & MOE & $\mathbf{E}-$ & - & + & - & - & . & . & - & . & . & - & . & & - & . & . & . & . & + & - & - & . & - & + & + & + & - \\
\hline
\end{tabular}

${ }^{1} \mathrm{pn}=$ postnatal; the sex was unknown for e13, e17, e21, pn1 and pn6

Figure 7

Summary of expression in mouse embryos (e) and early postnatal animals, compared to expression in adults.

dimer, the major allergen in the cat [42]. We argue, based on the evolutionary distances ( $K_{S}$ values) of the genes, that the alpha and beta/gamma-like genes of cat Fel $\mathrm{dI}$ are likely to be the orthologues of the Abpa and Abpbg genes. The median $K_{S}$ values between rodent $A b p a$ or Abpbg genes and cat Fel $\mathrm{dI}$ are 1.25 and 0.87 , respectively which are consistent with the reported substitution rate between rodent and cat orthologous sequence of 0.60 [43] given that neutral rates typically vary within the genome by up to 3 fold. Since the cat orthologue, like a number of Abpabg orthologues, is expressed mainly in salivary glands $[29,42]$ it is possible that the original function of the ancestral $A b p a / A b p b g$ genes involves secretion from salivary glands and subsequent application to the pelt of the animal.

The large cluster of mouse Abp paralogues qualifies in three respects as genes that are rapidly evolving under strong positive selection, namely elevated $\mathrm{K}_{\mathrm{A}} / \mathrm{K}_{\mathrm{S}}$ and a fast duplication rate, and now data showing rapid diversification of gene expression following duplication. The ques- tion is which of the four most likely adaptive functions best fits our current understanding of ABP: immunity, reproduction, chemosensation or toxin metabolism? Karn and Dlouhy [32] showed that salivary ABP is ubiquitous in Old World and New World rodents, regardless of their diets, and noted that ABP binds androgens specifically and with relatively high affinity (see also [44] and [41]). They speculated that the function of $\mathrm{ABP}$ must be one general to rodents, such as mate recognition, rather than a diet-specific one, such as toxin metabolism. The expression patterns we report here also augur against a role in toxin metabolism because we could not find expression of any of the $A b p$ paralogues in mouse liver or spleen, where detoxification of toxic metabolites might be expected to occur.

The developmental sequence of expression of these genes provides clues that help further narrow the choices of functional role for ABP. Abpa/Abpbg expression begins in the head of the embryo as early as 13 days of gestation, comprised of a relatively simple pattern of $a 11 / b g 11$ and 
bg10. By the first day of life, this has changed little, but by six days many other paralogues are expressed in the submaxillary and lacrimal glands. Expression proceeds to 15 days of life without yet revealing the sexually dimorphic patterns seen in several glands in adult mice. The transition to sexually dimorphic expression following puberty appears incompatible with roles for these in host immune defense.

It is fascinating that the MOE and VNO are the last tissues to achieve an adult expression pattern. Unlike the lacrimal gland and the salivary glands, these are not secretory tissues. It may be that early expression in the pups' secretory tissues provides signals by which the female parent recognizes her offspring. The pups would not need MOE and VNO expression themselves at this early stage. This distinction hints at a role for ABP in chemosensation, perhaps by participating in detection and recognition of $A B P$ subtypes. Paralogues expressed in the MOE and VNO could be involved in phenotype matching and/or in a system whereby a bound ligand is transferred between paralogues to augment the signal of a proteinaceous pheromone.

Recently, Grus et al. [45] studied V1R genes expressed in the VNOs of the dog, cow and opossum, reporting 8, 32 and 49 intact V1R genes, respectively, in these three species. The numbers of V1R genes in the genomes of mice and rats had been previously reported to be 187 and 102, respectively [46] while the human genome contains about 200 V1R genes, all but 4 of which appear to have been pseudogenized $[47,48]$. Grus et al. [45] showed a concordance between V1R repertoire size and the complexity of VNO morphology and suggested that these characteristics of the VNO are indicative of the sophistication of pheromone communications within species. These findings are particularly interesting in the context of Abp evolution. We previously reported finding a single, pseudogenized Abp gene pair in both the human and the chimpanzee genomes, while the genomes of the mouse and rat had approximately 14 and 3 pairs of $A b p$ genes, respectively, most of which had full-length ORFs [19]. A single, fulllength $A b p$ gene pair in each of the dog and cat genomes would be consistent with a pattern of increasing importance of $A b p$ genes in conspecific communication, proceeding from potentially no importance in primates to low importance in carnivores to relatively high importance in murid rodents, with the mouse utilizing the most number and diversity of $A b p$ gene pairs.

In our recent paper [19], we demonstrated extensive sequence diversification in the numerous $A b p a / A b p b g$ paralogues we predicted. In this report, we have shown that $A b p$ genes have evolved multiple, often distinct, expression patterns. Once these patterns are mapped to these genes' proposed phylogenetic tree a surprising lack of congruency is observed (Fig. 5): the evolution of gene expression appears not to recapitulate the evolution of coding sequence. Thus it appears that neofunctionalization, rather than neutral drift, has driven the evolution of these genes' expression patterns over relatively short time periods.

The extensive diversification in expression of this family of proteins provides two lines of evidence for a pheromonal role for ABP: 1) different patterns of $A b p a / A b p b g$ expression in different glands; and 2) sexual dimorphism in the expression of the paralogues in a subset of those glands. It is clear from our observations that expression patterns of many of the Abp paralogues differ dramatically among various glands that are located almost exclusively in the head and neck, where the sensory organs are located. Since mice are nocturnal, it is expected that they will make extensive use of olfactory as opposed to visual cues. The glands expressing Abp paralogues produce secretions (lacrimal and salivary) or detect odors (MOE and $\mathrm{VNO}$ ) and thus it appears highly likely that ABP proteins play a role in olfactory communication. This supports the earlier suggestion, based on behavioral testing, that salivary $\mathrm{ABP}$ (the Abpa gene, now Abpa11) mediates mate preference $[29,30]$. In the studies of Laukaitis et al., [29], females showed a stronger preference in experiments where the choice was between males tethered to the ends of the test chamber, than they did for the males' territories when the males were absent. Sniffing the face of the male would present the female with much more information (Fig. 4) than the male might leave in his territory in the form of shed skin flakes or hair which had been coated with saliva during grooming [29].

If the variety of proteins produced by expression of the mouse $A b p$ paralogues act as components of a complex pheromone system, then the secretions of the lacrimal gland and salivary glands provide a constellation of olfactory information, such as an animal's age and sex. Indeed it has been proposed previously that polymorphism in salivary ABP communicates the species/subspecies of the animal $[29-32,49]$. Thus we suggest that the strong evidence for involvement of $A b p$ paralogous genes in adaptive evolution is consistent with a pheromonal role for their protein products.

Laukaitis et al. [20] proposed that the region between $A b p a$ and $A b p b$ ( $a 11$ and $b g 11$ in [19] and in this study) could contain a sequence that coordinately regulates their expression. Emes et al. [19] suggested that this was possibly true of the bidirectional 5'-5' paired Abpa and Abpbg paralogue sets in general. The expression data we report here for $a 11$ and $b g 11$ is consistent with this idea since we have not seen either expressed independently of the other. 
However, it does not appear to hold true generally, since we observed independent expression of the members of a number of other pairs (e.g., bg10 in submaxillary and sublingual glands; $a 10$ in VNO and MOE, etc.). Thus, regulation of the expressions of Abpa and Abpbg members of pairs must be more complex than simple coordinate upor down-regulation of pairs. The lack of correlation between the evolutionary relationships of the Abpa/Abpbg paralogues [19] and their expression patterns (summarized in Fig. 5) support this notion, suggesting that sequences regulating expression of these genes have evolved in a manner that did not parallel the evolution of the structural genes. This implies rapid evolution of expression diversity in the Abpa/Abpbg paralogues.

Huminiecki and Wolfe [50] studied divergence of transcription profiles of genes in homologous tissues between human and mouse. They focused on loci where recent species-specific gene duplication occurred within one or the other species, allowing them to compare the transcription profiles of young paralogues in one species with a single orthologue in the other. They found that the presence of species-specific gene duplication accelerates the rate of expression divergence and that the recent duplicates are subject to reduced constraints on their protein sequences. In most cases, they observed that multiple changes in the spatial expression profile have occurred and they concluded that the expression in a new tissue suggests neofunctionalization. These results are consistent with those we reported earlier [19] and those that we report here for the recently and extensively duplicated Abpa/Abpbg genes in mice. This is perhaps an even more striking example because the single orthologous pair of Abpa/Abpbg genes in primates both degenerated into pseudogenes while expression in rodents has expanded into at least 9 tissues from the 2 tissues reported for the cat [42].

\section{Conclusion}

The multiple changes in the spatial expression profile of these genes resulting in various combinations of expression in glands and other organs in the head and face of the mouse strongly suggest that neofunctionalization of these genes, driven by adaptive evolution, has occurred following duplication. Primates represent an interesting contrast insofar as their single Abpa/Abpbg gene pair was pseudogenized, suggesting that its function has become dispensable. Many genes involved in olfactory and pheromonal cues have become pseudogenes in primates [40]. Evolutionary and expression information thus both indicate a role for $\mathrm{ABP}$ and its paralogues in pheromonal communication among mice and, perhaps in other animals, one that is likely to be less important in the primate line, at least in the great apes.

\section{Methods \\ Materials}

The $\mathrm{C} 3 \mathrm{H} / \mathrm{HeJ}$ inbred strain of mice was purchased from Jackson Laboratory (Bar Harbor, ME). Mice at age 75-80 days were sacrificed by cervical dislocation; tissues and organs were removed and frozen immediately in liquid nitrogen and thereafter stored at $-80^{\circ}$. Emes et al. [19] published the sequences of 14 Abpa paralogues and 13 Abpbg paralogues in mouse strain C57BL/6. Five of the Abpa paralogues and five of the Abpbg paralogues were predicted to be pseudogenes because of frameshifts and/ or termination codons occurring early in their sequences. Primer sets were designed to specific forward and reverse sequences for the remaining nine Abpa and eight Abpbg paralogues. Primers were designed to avoid cross-hybridization between paralogues' sequences. Primer sets were purchased from Sigma-Genosys (St. Louis, MO). DNA from strain C57BL/ 6 was obtained from Jackson Laboratory for use in testing the primer sets.

\section{RNA extraction, CDNA production and polymerase chain reaction (PCR)}

RNA was purified from mouse tissues with a Sigma total RNA purification kit (Sigma Biochemicals, St. Louis, MO). Absorbances at 260 and $280 \mathrm{~nm}$ were determined and used to calculate yield, purity and concentration of RNA from tissue extractions. In some instances, the RNA was treated with RNase-free DNase (Sigma Biochemicals). Oligo-dT was used to prime first-strand synthesis from 1 $\mu \mathrm{g}$ of total RNA per $20 \mu \mathrm{l}$ RT reaction essentially as described in [31] using Sigma AMV reverse transcriptase (Sigma Biochemicals). PCR was performed using Biolase (MidWest Scientific, St. Louis, MO) with $1 \mu \mathrm{l}$ of the RT reaction as previously described [31,33], using a $61^{\circ}$ annealing temperature and $20 \mathrm{sec}$ denaturing, annealing and extension times for 30 cycles. The products were separated on $2 \%$ agarose gels.

\section{DNA sequencing}

Clean-up of PCR templates was performed using QiaQuick PCR clean-up spin columns (Qiagen Incorporated, Valencia, CA) according to the manufacturers protocol (Qiagen Incorporated) and automated sequencing was performed by ACGT, Inc. (Chicago, IL).

\section{Authors' contributions}

This work arose from a comparative genomic analysis in which RDE, RCK, CML and CPP agreed to divide the bioinformatics analyses (published in 2004) and the expression analyses (this paper) between the two laboratories, Ponting's at Oxford University and Karn's at Butler University. SRD directed and participated in the harvesting of the many mouse tissues required for the study and he contributed to the design of the expression detection experiments. CML and RCK carried out the PCR expres- 
sion analyses. RDE and CPP created the annotated gene trees. All authors made substantive intellectual contributions to this work and all authors read and approved the final manuscript.

\section{Acknowledgements}

The authors thank M. Riley for assistance with dissections and J. Survance for help in obtaining embryos. This work was supported in part by the Holcomb Research Institute, Butler University. RDE and CPP were supported by the UK Medical Research Council. These sources of support are gratefully acknowledged.

\section{References}

I. Gibbs RA, Weinstock GM, Metzker ML, Muzny DM, Sodergren EJ, Scherer S, Scott G, Steffen D, Worley KC, Burch PE, Okwuonu G, Hines S, Lewis L, DeRamo C, Delgado O, Dugan-Rocha S, Miner G, Morgan M, Hawes A, Gill R, Celera, Holt RA, Adams MD, Amanatides PG, Baden-Tillson H, Barnstead M, Chin S, Evans CA, Ferriera S, Fosler C, Glodek A, Gu Z, Jennings D, Kraft CL, Nguyen T, Pfannkoch CM, Sitter C, Sutton GG, Venter JC, Woodage T, Smith D, Lee HM, Gustafson E, Cahill P, Kana A, Doucette-Stamm L, Weinstock K, Fechtel K, Weiss RB, Dunn DM, Green ED, Blakesley RW, Bouffard GG, De Jong PJ, Osoegawa K, Zhu B, Marra M, Schein J, Bosdet I, Fjell C, Jones S, Krzywinski M, Mathewson C, Siddiqui A, Wye N, McPherson J, Zhao S, Fraser CM, Shetty J, Shatsman S, Geer K, Chen Y, Abramzon S, Nierman WC, Havlak PH, Chen R, Durbin KJ, Egan A, Ren Y, Song XZ, Li B, Liu Y, Qin X, Cawley S, Worley KC, Cooney AJ, D'Souza LM, Martin K, Wu JQ, Gonzalez-Garay ML, Jackson AR, Kalafus KJ, McLeod MP, Milosavljevic A, Virk D, Volkov A, Wheeler DA, Zhang Z, Bailey JA, Eichler EE, Tuzun E, Birney E, Mongin E, Ureta-Vidal A, Woodwark C, Zdobnov E, Bork P, Suyama M, Torrents D, Alexandersson M, Trask BJ, Young JM, Huang $H$, Wang $H$, Xing H, Daniels S, Gietzen D, Schmidt J, Stevens K, Vitt U, Wingrove J, Camara F, Mar Alba M, Abril JF, Guigo R, Smit A, Dubchak I, Rubin EM, Couronne O, Poliakov A, Hubner N, Ganten D, Goesele C, Hummel O, Kreitler T, Lee YA, Monti J, Schulz H, Zimdahl H, Himmelbauer H, Lehrach H, Jacob HJ, Bromberg S, Gullings-Handley J, Jensen-Seaman MI, Kwitek AE, Lazar J, Pasko D, Tonellato PJ, Twigger S, Ponting CP, Duarte JM, Rice S, Goodstadt L, Beatson SA, Emes RD, Winter EE, Webber C, Brandt P, Nyakatura G, Adetobi M, Chiaromonte $F$, Elnitski L, Eswara P, Hardison RC, Hou M, Kolbe D, Makova K, Miller W, Nekrutenko A, Riemer C, Schwartz S, Taylor J, Yang S, Zhang Y, Lindpaintner K, Andrews TD, Caccamo M, Clamp M, Clarke L, Curwen V, Durbin R, Eyras E, Searle SM, Cooper GM, Batzoglou S, Brudno M, Sidow A, Stone EA, Venter JC, Payseur BA, Bourque G, Lopez-Otin C, Puente XS, Chakrabarti K, Chatterji S, Dewey C, Pachter L, Bray N, Yap VB, Caspi A, Tesler G, Pevzner PA, Haussler D, Roskin KM, Baertsch R, Clawson H, Furey TS, Hinrichs AS, Karolchik D, Kent W], Rosenbloom KR, Trumbower $H$, Weirauch $M$, Cooper DN, Stenson PD, Ma B, Brent M, Arumugam M, Shteynberg D, Copley RR, Taylor MS, Riethman H, Mudunuri U, Peterson J, Guyer M, Felsenfeld A, Old S, Mockrin S, Collins F: Genome sequence of the Brown Norway rat yields insights into mammalian evolution. Nature 2004, 428(6982):493-521.

2. Lander ES, Linton LM, Birren B, Nusbaum C, Zody MC, Baldwin J, Devon K, Dewar K, Doyle M, FitzHugh W, Funke R, Gage D, Harris K, Heaford A, Howland J, Kann L, Lehoczky J, LeVine R, McEwan P, McKernan K, Meldrim J, Mesirov JP, Miranda C, Morris W, Naylor J, Raymond C, Rosetti M, Santos R, Sheridan A, Sougnez C, StangeThomann N, Stojanovic N, Subramanian A, Wyman D, Rogers J, Sulston J, Ainscough R, Beck S, Bentley D, Burton J, Clee C, Carter N, Coulson A, Deadman R, Deloukas P, Dunham A, Dunham I, Durbin R, French L, Grafham D, Gregory S, Hubbard T, Humphray S, Hunt A, Jones M, Lloyd C, McMurray A, Matthews L, Mercer S, Milne S, Mullikin JC, Mungall A, Plumb R, Ross M, Shownkeen R, Sims S, Waterston RH, Wilson RK, Hillier LW, McPherson JD, Marra MA, Mardis ER, Fulton LA, Chinwalla AT, Pepin KH, Gish WR, Chissoe SL, WendI MC, Delehaunty KD, Miner TL, Delehaunty A, Kramer JB, Cook LL, Fulton RS, Johnson DL, Minx PJ, Clifton SW, Hawkins T, Branscomb E, Predki P, Richardson P, Wenning S, Slezak T, Doggett $\mathrm{N}$, Cheng JF, Olsen A, Lucas S, Elkin C, Uberbacher E, Frazier M, Gibbs RA, Muzny DM, Scherer SE, Bouck JB, Sodergren EJ, Worley
KC, Rives CM, Gorrell JH, Metzker ML, Naylor SL, Kucherlapati RS, Nelson DL, Weinstock GM, Sakaki Y, Fujiyama A, Hattori M, Yada T, Toyoda A, Itoh T, Kawagoe C, Watanabe H, Totoki Y, Taylor T, Weissenbach J, Heilig R, Saurin W, Artiguenave F, Brottier P, Bruls T, Pelletier E, Robert C, Wincker P, Smith DR, Doucette-Stamm L, Rubenfield M, Weinstock K, Lee HM, Dubois J, Rosenthal A, Platzer M, Nyakatura G, Taudien S, Rump A, Yang H, Yu J, Wang J, Huang G, Gu J, Hood L, Rowen L, Madan A, Qin S, Davis RW, Federspiel NA, Abola AP, Proctor MJ, Myers RM, Schmutz J, Dickson M, Grimwood J, Cox DR, Olson MV, Kaul R, Raymond C, Shimizu N, Kawasaki K, Minoshima S, Evans GA, Athanasiou M, Schultz R, Roe BA, Chen F, Pan H, Ramser J, Lehrach H, Reinhardt R, McCombie WR, de la Bastide M, Dedhia N, Blocker H, Hornischer K, Nordsiek G, Agarwala R, Aravind L, Bailey JA, Bateman A, Batzoglou S, Birney E, Bork P, Brown DG, Burge CB, Cerutti L, Chen HC, Church D, Clamp M, Copley RR, Doerks T, Eddy SR, Eichler EE, Furey TS, Galagan J, Gilbert JG, Harmon C, Hayashizaki Y, Haussler D, Hermjakob $H$, Hokamp K, Jang W, Johnson LS, Jones TA, Kasif S, Kaspryzk A, Kennedy S, Kent W], Kitts P, Koonin EV, Korf I, Kulp D, Lancet D, Lowe TM, McLysaght A, Mikkelsen T, Moran JV, Mulder N, Pollara VJ, Ponting CP, Schuler G, Schultz J, Slater G, Smit AF, Stupka E, Szustakowski J, Thierry-Mieg D, Thierry-Mieg J, Wagner L, Wallis J, Wheeler R, Williams A, Wolf YI, Wolfe KH, Yang SP, Yeh RF, Collins F, Guyer MS, Peterson J, Felsenfeld A, Wetterstrand KA, Patrinos A, Morgan MJ, de Jong P, Catanese JJ, Osoegawa K, Shizuya H, Choi S, Chen YJ: Initial sequencing and analysis of the human genome. Nature 200I, 409(6822):860-92I.

3. Waterston RH, Lindblad-Toh K, Birney E, Rogers J, Abril JF, Agarwal P, Agarwala R, Ainscough R, Alexandersson M, An P, Antonarakis SE, Attwood J, Baertsch R, Bailey J, Barlow K, Beck S, Berry E, Birren B, Bloom T, Bork P, Botcherby M, Bray N, Brent MR, Brown DG, Brown SD, Bult C, Burton J, Butler J, Campbell RD, Carninci P, Cawley S, Chiaromonte F, Chinwalla AT, Church DM, Clamp M, Clee C, Collins FS, Cook LL, Copley RR, Coulson A, Couronne O, Cuff J, Curwen V, Cutts T, Daly M, David R, Davies J, Delehaunty KD, Deri J, Dermitzakis ET, Dewey C, Dickens NJ, Diekhans M, Dodge S, Dubchak I, Dunn DM, Eddy SR, Elnitski L, Emes RD, Eswara P, Eyras E, Felsenfeld A, Fewell GA, Flicek P, Foley K, Frankel WN, Fulton LA, Fulton RS, Furey TS, Gage D, Gibbs RA, Glusman G, Gnerre S, Goldman N, Goodstadt L, Grafham D, Graves TA, Green ED, Gregory S, Guigo R, Guyer M, Hardison RC, Haussler D, Hayashizaki Y, Hillier LW, Hinrichs A, Hlavina W, Holzer T, Hsu F, Hua A, Hubbard T, Hunt A, Jackson I, Jaffe DB, Johnson LS, Jones M, Jones TA, Joy A, Kamal M, Karlsson EK, Karolchik D, Kasprzyk A, Kawai J, Keibler E, Kells C, Kent WJ, Kirby A, Kolbe DL, Korf I, Kucherlapati RS, Kulbokas EJ, Kulp D, Landers T, Leger JP, Leonard S, Letunic I, Levine R, Li J, Li M, Lloyd C, Lucas S, Ma B, Maglott DR, Mardis ER, Matthews L, Mauceli E, Mayer JH, McCarthy M, McCombie WR, McLaren S, McLay K, McPherson JD, Meldrim J, Meredith B, Mesirov JP, Miller W, Miner TL, Mongin E, Montgomery KT, Morgan M, Mott R, Mullikin JC, Muzny DM, Nash WE, Nelson JO, Nhan MN, Nicol R, Ning Z, Nusbaum C, O'Connor MJ, Okazaki Y, Oliver K, Overton-Larty E, Pachter L, Parra G, Pepin KH, Peterson J, Pevzner P, Plumb R, Pohl CS, Poliakov A, Ponce TC, Ponting CP, Potter S, Quail M, Reymond A, Roe BA, Roskin KM, Rubin EM, Rust AG, Santos R, Sapojnikov V, Schultz B, Schultz J, Schwartz MS, Schwartz S, Scott C, Seaman S, Searle S, Sharpe T, Sheridan A, Shownkeen R, Sims S, Singer JB, Slater G, Smit A, Smith DR, Spencer B, Stabenau A, Stange-Thomann N, Sugnet C, Suyama M, Tesler G, Thompson J, Torrents D, Trevaskis E, Tromp J, Ucla C, Ureta-Vidal A, Vinson JP, Von Niederhausern AC, Wade CM, Wall M, Weber RJ, Weiss RB, Wendl MC, West AP, Wetterstrand K, Wheeler R, Whelan S, Wierzbowski J, Willey D, Williams S, Wilson RK, Winter E, Worley KC, Wyman D, Yang S, Yang SP, Zdobnov EM, Zody MC, Lander ES: Initial sequencing and comparative analysis of the mouse genome. Nature 2002, 420(69 I5):520-562.

4. Li WH: Molecular Evolution. Sunderland, MA , Sinauer; 1997.

5. Makalowski W, Boguski MS: Evolutionary parameters of the transcribed mammalian genome: an analysis of 2,820 orthologous rodent and human sequences. Proc Natl Acad Sci U S A 1998, 95( I 6):9407-94|2.

6. Makalowski W, Boguski MS: Synonymous and nonsynonymous substitution distances are correlated in mouse and rat genes. | Mol Evol 1998, 47(2): | |9-121.

7. Winter EE, Goodstadt L, Ponting CP: Elevated rates of protein secretion, evolution, and disease among tissue-specific genes. Genome Res 2004, I4(I):54-6I. 
8. He X, Zhang J: Rapid subfunctionalization accompanied by prolonged and substantial neofunctionalization in duplicate gene evolution. Genetics 2005, I 69(2): I I 57-64. Epub 2005 Jan I6.

9. Lynch M, Katju V: The altered evolutionary trajectories of gene duplicates. Trends Genet 2004, 20(I I):544-549.

10. Ohno S: Evolution by Gene Duplication. Berlin, Springer; 1970.

II. Rastogi S, Liberles DA: Subfunctionalization of duplicated genes as a transition state to neofunctionalization. BMC Evol Biol 2005, 5(I):28.

12. Khaitovich P, Weiss G, Lachmann M, Hellmann I, Enard W, Muetzel $B$, Wirkner U, Ansorge W, Paabo S: A neutral model of transcriptome evolution. PLOS 2004, 2(5):682-689.

13. Yanai I, Graur D, Ophir R: Incongruent expression profiles between human and mouse orthologous genes suggest widespread neutral evolution of transcription control. Omics 2004 , 8(I): $15-24$.

14. Gu Z, Rifkin SA, White KP, Li WH: Duplicate genes increase gene expression diversity within and between species. Nat Genet 2004, 36(6):577-9. Epub 2004 May 2..

15. Su AI, Cooke MP, Ching KA, Hakak Y, Walker JR, Wiltshire T, Orth AP, Vega RG, Sapinoso LM, Moqrich A, Patapoutian A, Hampton GM, Schultz PG, Hogenesch JB: Large-scale analysis of the human and mouse transcriptomes. Proc Natl Acad Sci U S A 2002, 99:4465

16. Huminiecki L, Wolfe KH: Divergence of Spatial Gene Expression Profiles Following Species-Specific Gene Duplications in Human and Mouse. Genome Res 2004, 14:1870-1879.

17. Adkins RM, Gelke EL, Rowe D, Honeycutt RL: Molecular phylogeny and divergence time estimates for major rodent groups: evidence from multiple genes. Mol Biol Evol 200 I, I 8(5):777-79|

18. Springer MS, Murphy W], Eizirik E, O'Brien S]: Placental mammal diversification and the Cretaceous-Tertiary boundary. Proc Natl Acad Sci U S A 2003, 100(3): 1056-6I. Epub 2003 Jan 27.

19. Emes RD, Riley MC, Laukaitis CM, Goodstadt L, Karn RC, Ponting $\mathrm{CP}$ : Comparative evolutionary genomics of androgen-binding protein genes. Genome Research 2004, 14:1516-1529.

20. Laukaitis CM, Dlouhy RD, Karn RC: The mouse salivary androgen-binding protein (ABP) gene cluster on Chromosome 7: Characterization and evolutionary relationships. Mammalian Genome 2003, 14:679-69|.

21. Dlouhy SR, Taylor BA, Karn RC: The genes for mouse salivary Androgen-binding protein (ABP) subunits alpha and gamma are located on chromosome 7. Genetics 1987, I | 5:535-543.

22. Karn RC, Laukaitis CM: Characterization of two forms of mouse salivary androgen-binding protein (ABP): Implications for evolutionary relationships and ligand-binding function. Biochemistry 2003, 42(23):7162-7170.

23. Klug J, Beier HM, Bernard A, Chilton BS, Fleming TP, Lehrer RI, Miele L, Pattabiraman N, Singh G: Uteroglobin/Clara cell I 0-kDa family of proteins: nomenclature committee report. Annals of the New York Academy of Sciences 2000, 923:348-354

24. Mukherjee AB, Chilton BS: The Uteroglobin/Clara Cell Protein Family. In Annals of the New York Academy of Sciences Volume 923. The New York Academy of Sciences; 2000.

25. Laukaitis CM, Karn RC: Evolution of the secretoglobins: A genomic and proteomic view. Biological Journal of the Linnaean Society 2005, 84:493-50I.

26. Hillier LW, Miller W, Birney E, Warren W, Hardison RC, Ponting CP Bork P, Burt DW, Groenen MA, Delany ME, Dodgson JB, Chinwalla AT, Cliften PF, Clifton SW, Delehaunty KD, Fronick C, Fulton RS, Graves TA, Kremitzki C, Layman D, Magrini V, McPherson JD, Miner TL, Minx P, Nash WE, Nhan MN, Nelson JO, Oddy LG, Pohl CS, Randall-Maher J, Smith SM, Wallis JW, Yang SP, Romanov MN, Rondelli CM, Paton B, Smith J, Morrice D, Daniels L, Tempest HG, Robertson L, Masabanda JS, Griffin DK, Vignal A, Fillon V, Jacobbson L, Kerje S, Andersson L, Crooijmans RP, Aerts J, van der Poel J], Ellegren $H$, Caldwell RB, Hubbard SJ, Grafham DV, Kierzek AM, McLaren SR, Overton IM, Arakawa H, Beattie KJ, Bezzubov Y, Boardman PE, Bonfield JK, Croning MD, Davies RM, Francis MD, Humphray SJ, Scott CE, Taylor RG, Tickle C, Brown WR, Rogers J, Buerstedde JM, Wilson SA, Stubbs L, Ovcharenko I, Gordon L, Lucas S, Miller MM, Inoko H, Shiina T, Kaufman J, Salomonsen J, Skjoedt K, Wong GK, Wang J, Liu B, Wang J, Yu J, Yang H, Nefedov M, Koriabine M, Dejong PJ, Goodstadt L, Webber C, Dickens NJ, Letunic I, Suyama M, Torrents D, von Mering C, Zdobnov EM, Makova K, Nekrutenko A, Elnitski L, Eswara P, King DC, Yang S, Tyekucheva S, Radakrishnan A, Harris RS, Chi- aromonte F, Taylor J, He J, Rijnkels M, Griffiths-Jones S, Ureta-Vidal A, Hoffman MM, Severin J, Searle SM, Law AS, Speed D, Waddington D, Cheng Z, Tuzun E, Eichler E, Bao Z, Flicek P, Shteynberg DD, Brent MR, Bye JM, Huckle EJ, Chatterii S, Dewey C, Pachter L, Kouranov A Mourelatos Z, Hatzigeorgiou AG, Paterson AH, Ivarie R, Brandstrom M, Axelsson E, Backstrom N, Berlin S, Webster MT, Pourquie O, Reymond A, Ucla C, Antonarakis SE, Long M, Emerson J], Betran E, Dupanloup I, Kaessmann H, Hinrichs AS, Bejerano G, Furey TS, Harte RA, Raney B, Siepel A, Kent WJ, Haussler D, Eyras E, Castelo R, Abril JF, Castellano S, Camara F, Parra G, Guigo R, Bourque G, Tesler G, Pevzner PA, Smit A, Fulton LA, Mardis ER, Wilson RK: Sequence and comparative analysis of the chicken genome provide unique perspectives on vertebrate evolution. Nature 2004, 432(70 I 8):695-7|6.

27. Gail DB: Closing remarks and future directions (conference on the uteroglobin/clara cell protein family). Annals of the New York Academy of Sciences 2000, 923:355-356.

28. Singh G, Katyal SL: Clara cell proteins. Annals of the New York Academy of Sciences 2000, 923:43-58.

29. Laukaitis CM, Critser ES, Karn RC: Salivary androgen-binding protein (ABP) mediates sexual isolation in Mus musculus. Evolution 1997, 5 I(6):2000-2005.

30. Talley HM, Laukaitis CM, Karn RC: Female preference for male saliva: implications for sexual isolation of Mus musculus subspecies. Evolution 200I, 55:63I-634.

31. Hwang J, Hoffstetter JR, Bonhomme F, Karn RC: The microevolution of mouse salivary androgen-binding protein (ABP) paralleled subspeciation of Mus musculus. Journal of Heredity 1997, 88:93-97.

32. Karn RC, Dlouhy RD: Salivary androgen-binding protein variation in Mus and other rodents. Journal of Heredity 1991, 82:453-458.

33. Karn RC, Nachman MW: Reduced nucleotide variability at an androgen-binding protein locus (Abpa) in house mice: evidence for positive natural selection. Mol Biol Evol 1999, 16:1192-1197.

34. Karn RC, Orth A, Bonhomme F, Boursot P: The complex history of a gene proposed to participate in a sexual isolation mechanism in house mice. Mol Biol Evol 2002, 19(4):462-47I.

35. Simpson DA, Feeney S, Boyle C, Stitt AW: Retinal VEGF mRNA measured by SYBR green I fluorescence: A versatile approach to quantitative PCR. Mol Vis 2000, 6:178-183.

36. Sirover MA: New insights into an old protein: the functional diversity of mammalian glyceraldehyde-3-phosphate dehydrogenase. Biochim Biophys Acta 1999, 1432(2):159-184.

37. Dlouhy RD, Karn RC: The tissue source and cellular control of the apparent size of androgen binding protein (Abp), a mouse salivary protein whose electrophoretic mobility is under the control of Sex-limited saliva pattern (Ssp). Biochemical Genetics 1983, 21: 1057-1070.

38. Dlouhy RD, Nichols WC, Karn RC: Production of an antibody to mouse salivary androgen binding protein (ABP) and its use in identifying a prostate protein produced by a gene distinct from Abp. Biochem Genet 1986, 24:743-673.

39. Hurst LD, Smith NG: Do essential genes evolve slowly? Curr Biol 1999, 9 (I 4):747-750.

40. Emes RD, Goodstadt L, Winter EE, Ponting CP: Comparison of the genomes of human and mouse lays the foundation of genome zoology. Hum Mol Genet 2003, I 2(7):701-709.

4I. Karn RC, Clements MA: A comparison of the structures of the alpha:beta and alpha:gamma dimers of mouse salivary androgen-binding protein (ABP) and their differential steroid binding. Biochemical Genetics 1999, 37:187-199.

42. Morgenstern JP, Griffith IJ, Brauer AW, Rogers BL, Bond JF, Chapman MD, Kuo MC: Amino acid sequence of Fel dl, the major allergen of the domestic cat: protein sequence analysis and cDNA cloning. Proc Natl Acad Sci U S A I991, 88(2I):9690-9694.

43. Thomas JW, Touchman JW, Blakesley RW, Bouffard GG, BeckstromSternberg SM, Margulies EH, Blanchette M, Siepel AC, Thomas PJ, McDowell JC, Maskeri B, Hansen NF, Schwartz MS, Weber RJ, Kent WJ, Karolchik D, Bruen TC, Bevan R, Cutler DJ, Schwartz S, Elnitski L, Idol JR, Prasad AB, Lee-Lin SQ, Maduro VV, Summers TJ, Portnoy ME, Dietrich NL, Akhter N, Ayele K, Benjamin B, Cariaga K, Brinkley CP, Brooks SY, Granite S, Guan X, Gupta J, Haghighi P, Ho SL, Huang MC, Karlins E, Laric PL, Legaspi R, Lim MJ, Maduro QL, Masiello CA, Mastrian SD, McCloskey JC, Pearson R, Stantripop S, Tiongson EE, 
Tran JT, Tsurgeon C, Vogt LL, Walker MA, Wetherby KD, Wiggins LS, Young AC, Zhang LH, Osoegawa K, Zhu B, Zhao B, Shu CL, De Jong PJ, Lawrence CE, Smit AF, Chakravarti A, Haussler D, Green P, Miller W, Green ED: Comparative analyses of multi-species sequences from targeted genomic regions. Nature 2003, 424(6950):788-793.

44. Karn RC: Steroid binding by mouse salivary proteins. Biochemical Genetics 1998, 36:105-1 17.

45. Grus WE, Shi P, Zhang YP, Zhang J: Dramatic variation of the vomeronasal pheromone receptor gene repertoire among five orders of placental and marsupial mammals. Proc Natl Acad Sci U S A 2005, 102( 16):5767-72. Epub 2005 Mar 24.

46. Grus WE, Zhang J: Rapid turnover and species-specificity of vomeronasal pheromone receptor genes in mice and rats. Gene 2004, 340(2):303-3I2.

47. Rodriguez I, Mombaerts P: Novel human vomeronasal receptorlike genes reveal species-specific families. Curr Biol 2002, I 2(I 2):R409-II.

48. Zhang J, Webb DM: Evolutionary deterioration of the vomeronasal pheromone transduction pathway in catarrhine primates. Proc Natl Acad Sci U S A 2003, I 00( I4):8337-4I. Epub 2003 Jun 25 .

49. Karn RC, Russell R: The amino acid sequence of the alpha subunit of mouse salivary androgen-binding protein (ABP), with a comparison to the partial sequence of the beta subunit and to other ligand-binding proteins. Biochem Genet 1993, 3I(7) 8):307-319.

50. Huminiecki L, Wolfe KH: Divergence of spatial gene expression profiles following species-specific gene duplications in human and mouse. Genome Res 2004, I4(IOA):1870-1879.

Publish with Bio Med Central and every scientist can read your work free of charge

"BioMed Central will be the most significant development for disseminating the results of biomedical research in our lifetime. "

Sir Paul Nurse, Cancer Research UK

Your research papers will be:

- available free of charge to the entire biomedical community

- peer reviewed and published immediately upon acceptance

- cited in PubMed and archived on PubMed Central

- yours - you keep the copyright

Submit your manuscript here:

http://www.biomedcentral.com/info/publishing_adv.asp
BioMedcentral 